\title{
IL-33 Signaling in Lung Injury
}

Jing Chang, M.D., Ph.D., ${ }^{1,3^{*}}$ Yue-Feng Xia, M.D., Ph.D., ${ }^{2,3^{*}}$ Ma-Zhong Zhang, M.D., Ph.D., ${ }^{1}$ and Li-Ming Zhang, M.D. ${ }^{3}$

${ }^{1}$ Department of Anesthesiology, Shanghai Children's Medical Center, Shanghai Jiao-Tong University School of Medicine (SJTU-SM), Shanghai, P.R. China

${ }^{2}$ Department of Anesthesiology, Hunan Cancer Hospital, Xiangya School of Medicine, Central South University, Changsha, Hunan Province, P.R. China

${ }^{3}$ Department of Anesthesiology, University of Pittsburgh School of Medicine and University of Pittsburgh Medical Center, Pittsburgh, Pennsylvania, U.S.A.

*These authors contributed equally to this manuscript

\begin{abstract}
:
Interleukin (IL)-33, a member of the IL-1 cytokine super-family, acts as both a traditional cytokine and an intracellular nuclear factor. It is generally released from damaged immune cells and signals through its receptor ST2 in an autocrine and paracrine fashion, plays important roles in type- 2 innate immunity, and functions as an "alarmin" or a danger signal for cellular damage or cellular stress. Here, we review recent advances of the role of IL-33 in lung injury and explore its potential significance as an attractive therapeutic target.
\end{abstract}

Keywords: interleukin-33 (IL-33), lung injury, ventilator-induced lung injury (VILI)

\section{Introduction:}

Interleukin (IL)-33, previously known as "DVS27" [1], is a cytokine protein and ligand of the receptor ST2, a member of the Toll-like receptor (TLR)/IL-1 receptor (IL-IR) super-family[2]. Although ST2 was first reported in 1989 in both mice[3] and rats[4], IL33 wasn't identified and named until 2005 based on a computer database search for genes homologous to IL-1 family members[2].

IL-33 is an member of IL-1 cytokine family with $\sim 32$ $\mathrm{kD}$ and $18 \mathrm{kD}$ molecules that in the past represented uncleaved and mature IL -33 proteins, respectively[2, 5], but now represent the bioactive and cleavage forms
$[6,7]$, respectively. IL-33 appears to be a cytokine with dual functions: first, it acts as a conventional cytokine via activation of the ST2 receptor complex, and second, it performs as an intracellular nuclear factor with properties of transcriptional regulatory $[8,9]$. IL-33 plays an important role in type- 2 innate immunity and induces production of IL-5 and IL-13 by activating intracellular molecules via NF- $\kappa \mathrm{B}$ and MAP kinase signaling pathways [10-12]. IL-33 is also considered an "alarmin" which is promptly discharging from its producing cells upon cellular damage or cellular stress [11].

The function of IL-33 in different immune diseases has been well examined and reviewed. The role of IL-33 in lung injury was first identified mainly in lung inflammation and allergic diseases such as viral infection and asthma [13, 14]. In recent years, IL-33 has also been found to take part in other types of lung diseases such as ventilator-induced lung injury[15], acute lung injury, chronic obstructive pulmonary disease [16], lung cancer[17], and other clinical conditions. The purpose of the current review is to highlight the crucial role of IL-33 in lung injury and explore its potential as an attractive therapeutic target.

\section{IL-33 receptor activation and its signaling pathway}

IL-33 receptor is a complex that requires the expression of both ST2L, which is a member of the TLR/IL1R superfamily, and also the IL-1 receptor accessory 
protein (IL-1RAP) $[18,19]$. There are at least two other forms of ST receptors in addition to ST2L, including secreted soluble ST2 (sST2) that can serve as an allurement receptor for IL-33[20] and a ST2V variant that is present primarily in the human gut [21]. Soluble ST2 is considered a biomarker of several diseases, including cardiac disease[22], ulcerative colitis[23], and others.

IL-33 signaling starts from activation of cytoplasmic Toll-interleukin receptor domain which attracts the adaptor molecule myeloid differentiation primary response gene 88 (MyD88)[10, 24]. Then interleukin receptor-associated kinase 4 (IRAK4) is gathering to MyD88, followed by the interaction of myddosome which is composed of IRAK1, IRAK2, and/or IRAK3 $[25,26]$. This myddosome then combines with tumor necrosis factor receptor-associated factor 6 (TRAF6), which is crucial for signal propagation [27] and further activates transcription factors NF- $\kappa \mathrm{B}$ or mitogen-activated protein kinase (MAPK) [2, 9]. (Figure 1).

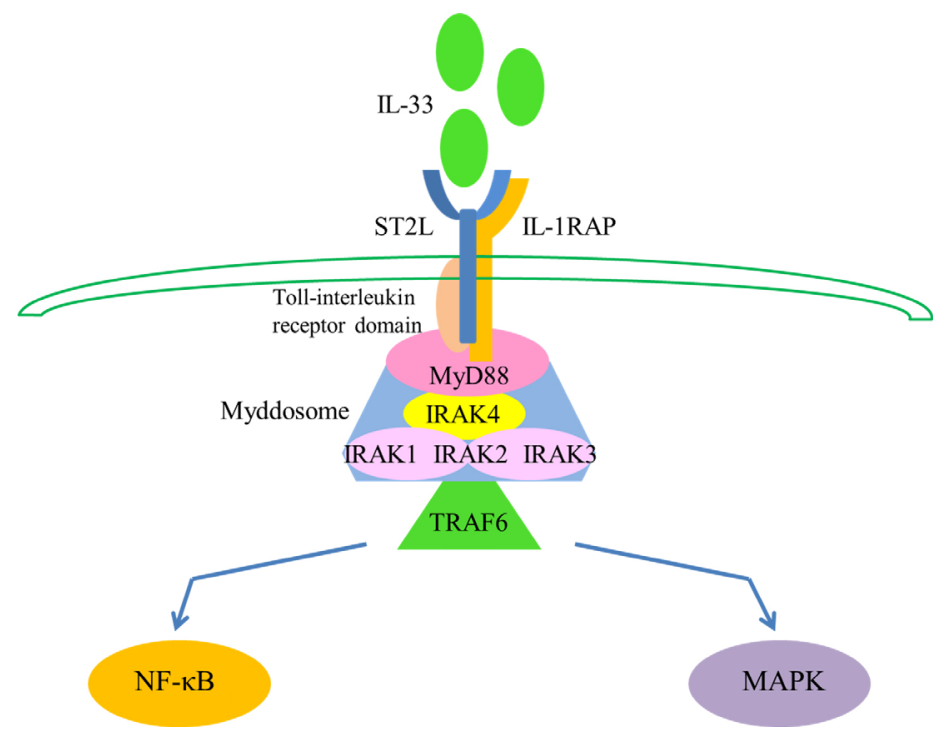

Figure 1. IL-33 signaling pathway. IL-33 first binds to a receptor complex, which is composed of ST2L and IL-1RAP. Signaling is induced through the cytoplasmic Toll-interleukin receptor domain and leads to the recruitment of MyD88; IRAK4 is then recruited to MyD88, followed by interaction between IRAK1, IRAK2, and/or IRAK3 to form a complex known as the myddosome. This myddosome then interacts with TRAF6 and further activates the transcription factors NF- $\mathrm{KB}$ or MAPK.

As a traditional cytokine, IL-33 stimulates Th2 cells, eosinophils, basophils and mast cells, to produce IL-4,
IL-5, IL-13 and some other type 2 cytokines, which stimulate the proliferation of $B$ cells, $T$ cells and have other critical immune-modulatory functions [24, 28, 29]. Function as a nuclear factor, IL-33 could also bind to NF- $\kappa$ B directly, sequestering it and diminishing its ability to turn on gene transcription [9].

\section{Release and cellular sources of IL-33 in the lung}

Even though it is well known that IL-33 expression is increased in inflamed tissue, controversy still exists regarding the active form of IL-33 and its releasing mechanism. Mature IL-33 (18kD) may be released during cellular necrosis, thereby acting as an "alarmin" $[11,30,31]$, whereas other studies showed that unlike IL-1 super-family members, full-length IL-33 does not need proteolysis for activation [6]. IL-33 is not activated by caspase 1 cleavage, but is processed into a mature bioactive form in neutrophils by elastase and cathepsin G [7]. The bioactivity of IL-33 is diminished in apoptotic cells through caspase-dependent proteolysis $[6,32]$.

There are various cellular sources of IL-33 in the lung. IL-33 expression in different cell types has been confirmed in individual studies and has been well-reviewed by Mirchandani et al[10]. Recent studies by Pichery et al., who generated an Il-33 Gt/ Gt which means I1-33-LacZ gene trap reporter strain, showed that using this innovative tool to examine expression of endogenous IL-33 in vivo revealed that an endogenous IL-33 protein was highly expressed in mouse lung cuboidal epithelium and other epithelial barrier tissues[33]. Importantly, they demonstrated that IL-33 protein was localized mainly in the cell nucleus, but not in the cytoplasm of producing cells [33]. Mirchandani et al. showed that IL-33 protein increased in whole lung homogenates of BALB/c mice after 6-12 hours of chitin challenge[34] and further demonstrated that this expression of IL-33 was mainly from alveolar type II cells [35]. A recent study by Kaur D et al. showed that bronchial epithelium, airway smooth muscle (ASM), and mast cells expressed IL-33 correlating with airway hyper-responsiveness (AHR) in latter asthma. Thus, it seems that IL-33 acts via autocrine and paracrine pathways and may function as an important target to modulate the crosstalk between mast cells and ASM [36].

\section{Role of IL-33 in lung injury}




\section{Inflammation and allergy in the lung}

Lung inflammation and allergies activate the innate immune response. Immune cells, along with macrophages, monocytes, and neutrophils, migrate into the lungs and further activate the pro-inflammatory response by releasing cytokines and chemokines, leading to the immune response[37].

Considering IL-33 as an "alarmin" of Th2 immune responses, its role in lung inflammation and allergy has been well-studied. In virus-induced lung inflammation and the cysteine protease-induced lung inflammation model, there will always be an obvious increase in the production of IL-33 with an enhanced expression of ST2 Mrna [38-41]. These results show that IL-33/ ST2 signaling participates in Th2-mediated airway inflammation. As a pro-inflammation "alarmin", IL-33 itself could also induce airway inflammation, followed by group 2 innate lymphoid cell activation, eosinophil infiltration[42], and IL-8 up-regulation[43]. IL-33 can activate both ERK and p38 MAPK in primary endothelial cells, however it can only stimulate ERK in epithelial cells in vitro [43].

Asthma is considered as a common life-long chronic disease and is classically characterized by serum $\mathrm{IgE}$ levels elevation, airway hyper-responsiveness, allergic inflammation, and increased Th2 cytokine production[14]. The roles of IL-33 in asthma have been well studied $[13,14]$. More recent research has implicated additional roles for IL-33 in asthma. It is plausible that IL-33 drives airway hyper-responsiveness (AHR) through directly stimulating mast cell activation and airway smooth muscle (ASM) wound repair and indirectly promoting ASM contraction via upregulation of mast cell-derived IL-13. The receptor for advanced glycation end-products (RAGE) was found to drive asthma/allergic airway inflammation by stimulating IL-33 expression in response to allergen and by directing the inflammatory response downstream of IL-33[44]. To clarify distinctions between the functions of IL-25 and IL-33 in asthma, the IL33 -induced response was identified by more sustained laying down of extracellular matrix protein, neo-angiogenesis, and T helper type 2 (Th2) cytokine expression and elevation of tissue damping compared with IL-25[45]. IL-33 also plays a significant role in pediatric asthma. Severe asthma with fungal sensitization (SAFS) was associated with higher levels of airway
IL-33, and alternate exposure induced increasing IL-3-mediated ILC2 numbers, steroid-resistant AHR and Th2 cell numbers. IL-33 might be considered as a unique therapeutic target for SAFS [46]. Elevated innate cytokines interleukin IL-33 and IL-25 and peculiar molecular responses in the interferon pathway are associated with rhinoviral infections in children. IL-33 also increased in fungal allergen-induced exacerbations, highlighting it as an attractive therapeutic target[47].

House dust mites (HDMs) are a leading source of allergens in patients with allergic disorders such as atopic dermatitis, asthma, and rhinitis [48], and administration of HDM extracts to mice induces allergic airway inflammation with similarities to asthma [49]. Full-length and bioactive IL-33 expression increased in caspase-1-deficient mice exposed to HDM, followed by a marked eosinophil recruitment. Using soluble ST2 receptor to neutralize IL-33 inhibited the enhanced allergic inflammation, while administering recombinant IL-33 enhanced allergic inflammation in caspase-1-deficient mice[50]. IL-33 was also needed to induce a humoral immune reaction to a single inhalational challenge to a HDM-pulsed dendritic cell-derived Th2 response [51-53]. Other research using chitin, a component of the exoskeleton of many organisms including HDM, indicates that uncleaved chitin promotes IL-33 release, whereas cleaved chitin could induce the activation of caspase- 1 and caspase-7, which promotes IL-33 inactivation and further results in the resolution of type 2 immune responses[54].

\section{Acute lung injury and ventilator-induced lung injury}

Although mortality from acute lung injury (ALI) or its severe form, acute respiratory distress syndrome (ARDS) has decreased substantially over the past 30 years, it still remains a high rate of morbidity and mortality $[55,56]$. Surviving patients in intensive care units have long term disability and high mortality rates years after discharge. Mechanical ventilation, acting as a most significant supportive measure in ALI[57], may produce an iatrogenic complication called ventilator-induced lung injury (VILI). Nonetheless, the etiology of VILI remains unclear. Very few studies have focused on this aspect of IL-33. One recent study[15] investigated IL-33/ST2 signaling in 
rat VILI model. Ventilation at $10 \mathrm{cmH}_{2} \mathrm{O}$ of inspiratory pressure for four hours elicited a high expression of IL-33 expression in lung tissues with increased membrane ST2L but decreased cytosol ST2L, indicating translocation of ST2L from the cytosol to the cell membranes of lung tissue. Using a mechanical stretch model for lung epithelium, we found that lung epithelial cells were able to release IL-33 following mechanical stretch (unpublished data). These results indicated that IL-33/ST2 signaling might participate in the process of VILI. Further experiments should need to confirm the role and significance of IL-33 in VILI.

\section{Chronic obstructive pulmonary disease}

Chronic obstructive pulmonary disease (COPD) is considered as one of the major concerns in public health and is estimated to rank as the third worldwide for mortality[58]. Cigarette smoke exposure is considered the leading causative agent of COPD. There is no effective treatment for COPD, and the mechanism by which the interaction between smoking and infection aggravate COPD remains poorly understood[16]. Kearley et al. [59] showed that cigarette smoke altered the lung microenvironment to facilitate an alternative IL-33-dependent magnified pro-inflammatory response to infection, leading to exacerbated COPD. They first exposed ST2- or IL-33-deficient mice or wild-type control mice to cigarette smoke and subsequently infected them with influenza A virus. Significantly enhanced weight loss and exaggerated lung inflammation occurred compared to viral infection alone in ST2- or IL-33 deficient mice, indicating that administration of ST2 could protect mice from exacerbated inflammation. These results showed that IL-33 is an essential trigger of COPD aggravation in mice by augmenting the inflammatory response. Other studies also demonstrated that increasing IL-33 expression in COPD [60] and altered IL-33 expression and release in airway epithelial cells is induced by cigarette smoke [61].

\section{Lung cancer and pulmonary sarcoidosis}

Immunoregulatory cytokines may play an important role in the metastases and growth of tumor. Sarcoidosis is also characterized as a multisystem immunologic disorder. As an "alarmin" in type-2 innate immunity and innate lymphoid cells (ILC2), IL-33 plays a significant role in lung cancer and pulmonary sarcoidosis. Kim et al. [17] evaluated the role of plasma IL-33 levels in the development of lung cancer and showed that cancer patients have lower levels of IL-33 than normal control subjects and that IL-33 decreased in a stage-dependent manner. Moreover, plasma IL-33 levels gradually reduced after surgical resection of malignant lesions, but were unchanged after chemotherapy. Together with cytokines IL-4 and IL-10, IL-33 may also be considered a potential immunotherapy biomarker in cancer research [62]. Moreover, because strongly correlation with systemic disease has been shown only between IL-33 expression and sarcoidosis but not other granulomatous diseases, IL-33 appears to be a new marker of pulmonary sarcoidosis $[63,64]$ and might serve as an adjunct diagnostic marker $[64,65]$.

\section{Other kinds of lung injury}

IL-33 also plays an essential role in other types of lung injuries such as interstitial lung disease, idiopathic pulmonary fibrosis, and malaria-associated lung injury. Luzina et al.[65] demonstrated that bleomycin injury combined with full-length IL-33 expression exerted a synergistic pulmonary lymphocyte effect and collagen accumulation. In addition, the expressions of several heat shock proteins were increased with full-length IL-33 treatment. Li et al. [66] showed that IL-33 was mainly expressed in lung epithelial cells, but was induced in macrophages by bleomycin. Deficiency of ST2, treatment with anti-IL-33 antibody, or attenuated alveolar macrophage depletion, as well as exogenous IL-33 enhanced bleomycin-inducing lung inflammation and fibrosis. Ampawong et al.[67] compared the histopathological specialties of lung injury in Southeast Asian patients who died from severe malaria and investigated whether a correlation to pulmonary edema was present. They showed that IL-33 expression in bronchial cells was dramatically increased in severe malaria patients who also suffered from pulmonary edema. These results suggest that IL-33 may take part in the pathogenic process of lung injury during severe malaria.

\section{Summary}

As stated above, IL-33 seems to function as a potent activator in various types of lung injury (Figure 2). IL-33/ST2 signal transduction could be considered as a molecular target to treat human diseases such as asthma [45, 47], ALI/ARDS [68], and so forth. Con- 


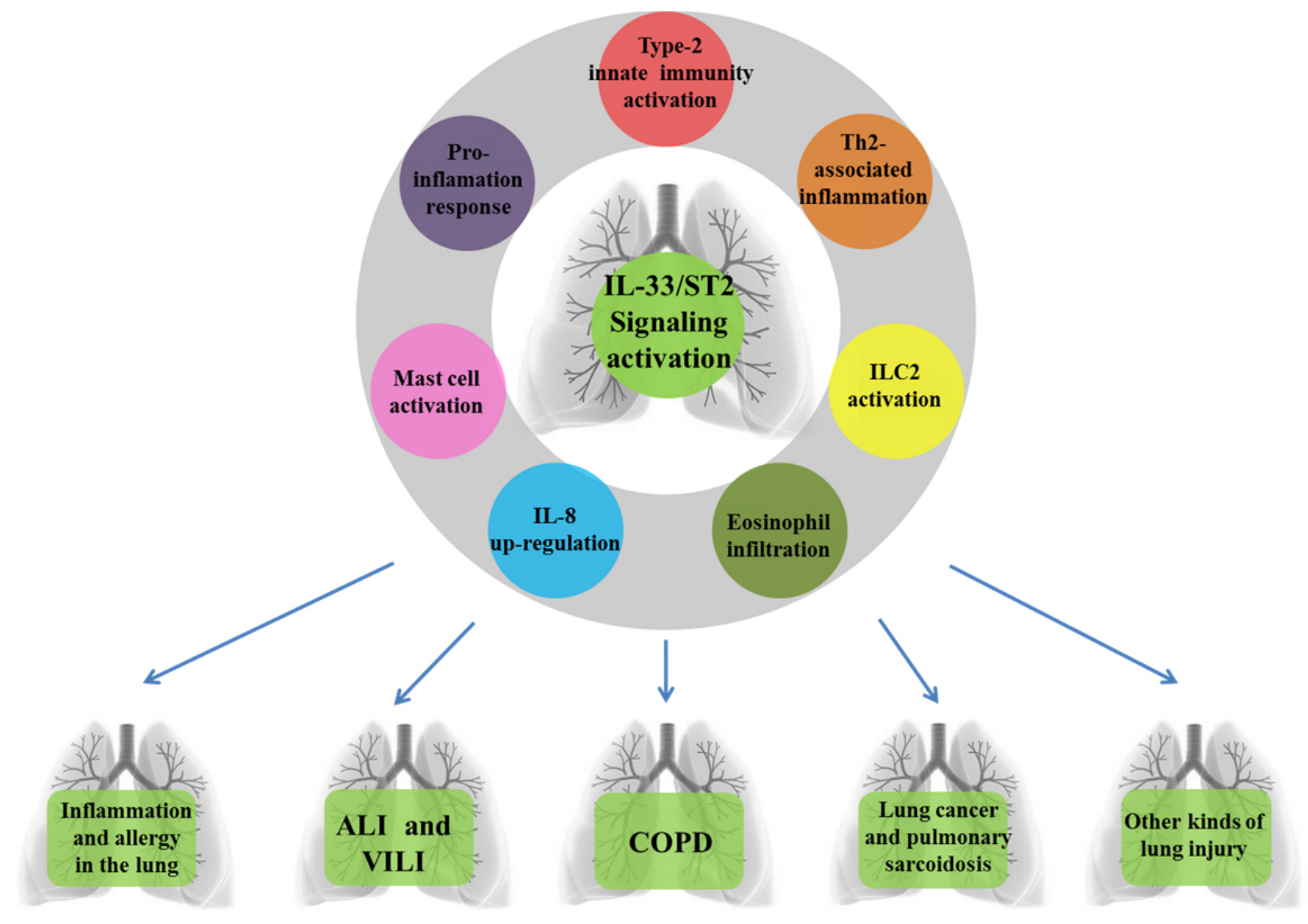

Figure 2. IL-33/ST2 signaling participates in various types of lung injury. IL-33 /ST2 signaling activation followed by type-2 innate immunity activation, Th2-associated airway inflammation, group 2 innate lymphoid cell (ILC2) activation, eosinophil infiltration, IL-8 up-regulation, mast cell activation and pro-inflammation response, further participates in lung inflammation and allergy, acute lung injury (ALI) and ventilator-induced lung injury (VILI), chronic obstructive pulmonary disease (COPD), lung cancer and pulmonary sarcoidosis and other kinds of lung injury.

sidering IL-33 as an "alarmin" cytokine, studies have tried to modulate the IL-33/ST2 signal, including both IL-33/ ST2L (membrane receptor and IL-33 complex) and IL-33/sST2 (soluble form and IL-33 complex). For example, vitamin D upregulated the sST2 production in a dose-dependent fashion, leading to inhibit the IL-33 cytokine response [69]. Endogenous IL-33 can be released from the respiratory epithelium upon stimulation to elicit an immune response. However, secreted, biologically-active IL-33 can be inactivated rapidly via the formation of a disulphide bonded form of IL-33. Such a mechanism limits the duration, rang of immunological responses to airway stimuli which dependent on ST2 [70]. RAGE recognizes ligands such as high-mobility group box 1 , and its pathway has been reported to play an important role in ALI. RAGE-deficient mice demonstrated increased IL-33 levels in the lung, leading to enhanced innate AHR, whereas blockade of IL-33 receptor ST2 sup- pressed innate AHR [71]. Vaccination against IL-33 has already been used in research to inhibit hyper-responsiveness and inflammation [72, 73]. Rebamipide, a widely-used medication for mucosal protection, showed an inhibitory effect on IL-33 production and an improving mite-induced asthma conditions[74], as did dietary galacto-oligosaccharides on IL-33[75].

In conclusion, IL-33 appears to be a crucial cytokine in modulating immune responses in several lung diseases, particularly in hyper-responsiveness and inflammation. Further research on its role in VILI is worth further pursuing. IL-33 has shown potential as an attractive therapeutic target.

\section{Acknowledgements}

We thank Ms. Christine Heiner, Scientific Writer in the 
Department of Anesthesiology and Surgery at the Uni-

versity of Pittsburgh, for assistance with scientific editing that greatly improved the manuscript. We would also like to show our gratitude to Ms. Karla Woosloose, laboratory manager, for providing comments on an earlier version of the manuscript.

\section{Conflict Interests Disclosure:}

The authors have no conflicting interests to disclose.

Corresponding Author:Correspondence: Address correspondence to: Dr. Li-Ming Zhang, Dept. of Anesthesiology, UPMC, 200 Lothrop Street, MUH Suite N-463, Pittsburgh, Pennsylvania 15213. E-mail: zhang11@ anes.upmc.edu.

Tel: 412-648-6077. Fax: 412-648-6014

Editor: Renyu Liu, MD; PhD. Associate Professor, Director of Preoperative Medicine, Department of Anesthesiology and Critical Care; Perelman School of Medicine at the University of Pennsylvania, 336 John Morgan building, 3620 Hamilton Walk, Philadelphia, PA 19104 . Phone: 2157461485 ; FAX: 2153495078

liur@uphs.upenn.edu

\section{Disclosure of Funding}

This research was supported by NIGMS R01GM108639-

01A1 grant 1151456 to Zhang L.

Additional publication details

Journal short name: Transl Perioper \& Pain Med

Received Date:Feb 29, 2016

Accepted Date: March 1, 2016

Published Date: March 31, 2016

Transl Perioper \& Pain Med 2016; 1(2):24-33

\section{Citation and Copyright}

Citation: Chang J, Xia Y, Zhang M, Zhang L. IL-33 Signaling in Lung Injury.Transl Perioper \& Pain Med 2016; $1(2): 24-33$

Copyright: (C) 2016 Chang J. et al. This is an open-access article distributed under the terms of the Creative Commons Attribution License, which permits unrestricted use, distribution, and reproduction in any medium, provided the original author and source are credited.

\section{References}

1. Onda H, Kasuya H, Takakura K, Hori T, Imaizumi $\mathrm{T}$, Takeuchi $\mathrm{T}$, et al. Identification of genes differentially expressed in canine vasospastic cerebral arteries after subarachnoid hemorrhage. Journal of cerebral blood flow and metabolism : official journal of the International Society of Cerebral Blood Flow and Metabolism. 1999;19(11):127988.

2. Schmitz J, Owyang A, Oldham E, Song Y, Murphy E, McClanahan TK, et al. IL-33, an interleukin-1-like cytokine that signals via the IL-1 receptor-related protein ST2 and induces $\mathrm{T}$ helper type 2 -associated cytokines. Immunity. 2005;23(5):479-90.

3. Tominaga S. A putative protein of a growth specific cDNA from BALB/c-3T3 cells is highly similar to the extracellular portion of mouse interleukin 1 receptor. FEBS letters. 1989;258(2):301-4.

4. Klemenz R, Hoffmann S, Werenskiold AK. Serumand oncoprotein-mediated induction of a gene with sequence similarity to the gene encoding carcinoembryonic antigen. Proceedings of the National Academy of Sciences of the United States of America. 1989;86(15):5708-12.

5. Kumar S, Minnich MD, Young PR. ST2/T1 protein functionally binds to two secreted proteins from Balb/c 3T3 and human umbilical vein endothelial cells but does not bind interleukin 1 . The Journal of biological chemistry. 1995;270(46):27905-13.

6. Luthi AU, Cullen SP, McNeela EA, Duriez PJ, Afonina IS, Sheridan C, et al. Suppression of interleukin-33 bioactivity through proteolysis by apoptotic caspases. Immunity. 2009;31(1):84-98.

7. Lefrancais E, Roga S, Gautier V, Gonzalez-de-Peredo A, Monsarrat B, Girard JP, et al. IL-33 is processed into mature bioactive forms by neutrophil elastase and cathepsin G. Proceedings of the National Academy of Sciences of the United States of America. 2012;109(5):1673-8.

8. Haraldsen G, Balogh J, Pollheimer J, Sponheim J, Kuchler AM. Interleukin-33 - cytokine of dual function or novel alarmin? Trends in immunology. 2009;30(5):227-33.

9. Ali S, Mohs A, Thomas M, Klare J, Ross R, Schmitz $\mathrm{ML}$, et al. The dual function cytokine IL-33 interacts with the transcription factor NF-kappaB to dampen NF-kappaB-stimulated gene transcription. Journal of immunology. 2011;187(4):1609-16. 
10. Mirchandani AS, Salmond RJ, Liew FY. Interleukin-33 and the function of innate lymphoid cells. Trends in immunology. 2012;33(8):389-96.

11. Cayrol C, Girard JP. IL-33: an alarmin cytokine with crucial roles in innate immunity, inflammation and allergy. Current opinion in immunology. 2014;31:31-7.

12. Lott JM, Sumpter TL, Turnquist HR. New dog and new tricks: evolving roles for IL-33 in type 2 immunity. Journal of leukocyte biology. 2015;97(6):1037-48.

13. Lloyd CM. IL-33 family members and asthma bridging innate and adaptive immune responses. Current opinion in immunology. 2010;22(6):800-6.

14. Miller AM. Role of IL-33 in inflammation and disease. Journal of inflammation. 2011;8(1):22.

15. Yang SH, Lin JC, Wu SY, Huang KL, Jung F, Ma $\mathrm{MC}$, et al. Membrane translocation of IL-33 receptor in ventilator induced lung injury. PloS one. 2015;10(3):e0121391.

16. Liew FY. Cigarette smoke resets the Alarmin IL-33 in COPD. Immunity. 2015;42(3):401-3.

17. Kim MS, Kim E, Heo JS, Bae DJ, Lee JU, Lee TH, et al. Circulating IL-33 level is associated with the progression of lung cancer. Lung cancer. 2015;90(2):346-51.

18. Ali S, Huber M, Kollewe C, Bischoff SC, Falk W, Martin MU. IL-1 receptor accessory protein is essential for IL-33-induced activation of T lymphocytes and mast cells. Proceedings of the National Academy of Sciences of the United States of America. 2007;104(47):18660-5.

19. Palmer G, Lipsky BP, Smithgall MD, Meininger D, Siu S, Talabot-Ayer D, et al. The IL-1 receptor accessory protein (AcP) is required for IL-33 signaling and soluble AcP enhances the ability of soluble ST2 to inhibit IL-33. Cytokine. 2008;42(3):358-64.

20. Hayakawa H, Hayakawa M, Kume A, Tominaga S. Soluble ST2 blocks interleukin-33 signaling in allergic airway inflammation. The Journal of biological chemistry. 2007;282(36):26369-80.

21. Tago K, Noda T, Hayakawa M, Iwahana H, Yanagisawa K, Yashiro T, et al. Tissue distribution and subcellular localization of a variant form of the human ST2 gene product, ST2V. Biochemical and biophysical research communications. 2001;285(5):1377-83.

22. Pascual-Figal DA, Lax A, Perez-Martinez MT, Del Carmen Asensio-Lopez M, Sanchez-Mas J, Network G. Clinical relevance of sST2 in cardiac diseases. Clinical chemistry and laboratory medicine : CCLM / FESCC. 2015.
23. Diaz-Jimenez D, Nunez LE, Beltran CJ, Candia E, Suazo C, Alvarez-Lobos M, et al. Soluble ST2: a new and promising activity marker in ulcerative colitis. World journal of gastroenterology. 2011;17(17):2181-90.

24. Cohen P. The TLR and IL-1 signalling network at a glance. Journal of cell science. 2014;127(Pt 11):2383-90.

25. Motshwene PG, Moncrieffe MC, Grossmann JG, Kao C, Ayaluru M, Sandercock AM, et al. An oligomeric signaling platform formed by the Toll-like receptor signal transducers MyD88 and IRAK-4. The Journal of biological chemistry. 2009;284(37):25404-11.

26. Lin SC, Lo YC, Wu H. Helical assembly in the MyD88-IRAK4-IRAK2 complex in TLR/IL-1R signalling. Nature. 2010;465(7300):885-90.

27. Ye H, Arron JR, Lamothe B, Cirilli M, Kobayashi T, Shevde NK, et al. Distinct molecular mechanism for initiating TRAF6 signalling. Nature. 2002;418(6896):443-7.

28. Dinarello CA. Interleukin-1 in the pathogenesis and treatment of inflammatory diseases. Blood. 2011;117(14):3720-32.

29. Garlanda C, Dinarello CA, Mantovani A. The interleukin-1 family: back to the future. Immunity. 2013;39(6):1003-18.

30. Cayrol C, Girard JP. The IL-1-like cytokine IL-33 is inactivated after maturation by caspase- 1 . Proceedings of the National Academy of Sciences of the United States of America. 2009;106(22):9021-6.

31. Talabot-Ayer D, Lamacchia C, Gabay C, Palmer G. Interleukin-33 is biologically active independently of caspase-1 cleavage. The Journal of biological chemistry. 2009;284(29):19420-6.

32. Lamkanfi M, Dixit VM. IL-33 raises alarm. Immunity. 2009;31(1):5-7.

33. Pichery M, Mirey E, Mercier P, Lefrancais E, Dujardin A, Ortega N, et al. Endogenous IL-33 is highly expressed in mouse epithelial barrier tissues, lymphoid organs, brain, embryos, and inflamed tissues: in situ analysis using a novel Il-33-LacZ gene trap reporter strain. Journal of immunology. 2012;188(7):3488-95.

34. Van Dyken SJ, Mohapatra A, Nussbaum JC, Molofsky AB, Thornton EE, Ziegler SF, et al. Chitin activates parallel immune modules that direct distinct inflammatory responses via innate lymphoid type 2 and gammadelta $T$ cells. Immunity. 2014;40(3):414-24.

35. Mohapatra A, Van Dyken SJ, Schneider C, Nuss- 
baum JC, Liang HE, Locksley RM. Group 2 innate lymphoid cells utilize the IRF4-IL-9 module to coordinate epithelial cell maintenance of lung homeostasis. Mucosal immunology. 2015.

36. Kaur D, Gomez E, Doe C, Berair R, Woodman L, Saunders R, et al. IL-33 drives airway hyper-responsiveness through IL-13-mediated mast cell: airway smooth muscle crosstalk. Allergy. 2015;70(5):556-67.

37. Kishore A, Borucka J, Petrkova J, Petrek M. Novel insights into miRNA in lung and heart inflammatory diseases. Mediators of inflammation. 2014;2014:259131.

38. Zeng S, Wu J, Liu J, Qi F, Liu B. IL-33 Receptor (ST2) Signalling is Important for Regulation of Th2-Mediated Airway Inflammation in a Murine Model of Acute Respiratory Syncytial Virus Infection. Scandinavian journal of immunology. 2015;81(6):494-501.

39. Mehta AK, Duan W, Doerner AM, Traves SL, Broide DH, Proud D, et al. Rhinovirus infection interferes with induction of tolerance to aeroantigens through OX40 ligand, thymic stromal lymphopoietin, and IL-33. The Journal of allergy and clinical immunology. 2015.

40. Jackson DJ, Makrinioti H, Rana BM, Shamji BW, Trujillo-Torralbo MB, Footitt J, et al. IL-33-dependent type 2 inflammation during rhinovirus-induced asthma exacerbations in vivo. American journal of respiratory and critical care medicine. 2014;190(12):1373-82.

41. Morita $\mathrm{H}$, Arae K, Unno H, Miyauchi K, Toyama $\mathrm{S}$, Nambu A, et al. An Interleukin-33-Mast Cell-Interleukin-2 Axis Suppresses Papain-Induced Allergic Inflammation by Promoting Regulatory T Cell Numbers. Immunity. 2015;43(1):175-86.

42. Paclik D, Stehle C, Lahmann A, Hutloff A, Romagnani C. ICOS regulates the pool of group 2 innate lymphoid cells under homeostatic and inflammatory conditions in mice. European journal of immunology. 2015;45(10):276672.

43. Yagami A, Orihara K, Morita H, Futamura K, Hashimoto N, Matsumoto K, et al. IL-33 mediates inflammatory responses in human lung tissue cells. Journal of immunology. 2010;185(10):5743-50.

44. Oczypok EA, Milutinovic PS, Alcorn JF, Khare A, Crum LT, Manni ML, et al. Pulmonary receptor for advanced glycation end-products promotes asthma pathogenesis through IL-33 and accumulation of group 2 innate lymphoid cells. The Journal of allergy and clinical immunology. 2015;136(3):747-56 e4.
45. Li Y, Wang W, Huang P, Zhang Q, Yao X, Wang J, et al. Distinct sustained structural and functional effects of interleukin-33 and interleukin-25 on the airways in a murine asthma surrogate. Immunology. 2015;145(4):508-18.

46. Castanhinha S, Sherburn R, Walker S, Gupta A, Bossley CJ, Buckley J, et al. Pediatric severe asthma with fungal sensitization is mediated by steroid-resistant IL-33. The Journal of allergy and clinical immunology. 2015;136(2):312-22 e7.

47. Cook J, Saglani S. Pathogenesis and prevention strategies of severe asthma exacerbations in children. Current opinion in pulmonary medicine. 2015.

48. Gregory LG, Lloyd CM. Orchestrating house dust mite-associated allergy in the lung. Trends in immunology. 2011;32(9):402-11.

49. Johnson JR, Wiley RE, Fattouh R, Swirski FK, Gajewska BU, Coyle AJ, et al. Continuous exposure to house dust mite elicits chronic airway inflammation and structural remodeling. American journal of respiratory and critical care medicine. 2004;169(3):378-85.

50. Madouri F, Guillou N, Fauconnier L, Marchiol T, Rouxel N, Chenuet P, et al. Caspase-1 activation by NLRP3 inflammasome dampens IL-33-dependent house dust mite-induced allergic lung inflammation. Journal of molecular cell biology. 2015;7(4):351-65.

51. Canbaz D, Utsch L, Logiantara A, van Ree R, van Rijt LS. IL-33 promotes the induction of immunoglobulin production after inhalation of house dust mite extract in mice. Allergy. 2015;70(5):522-32.

52. Moran TP, Nakano K, Whitehead GS, Thomas SY, Cook DN, Nakano H. Inhaled house dust programs pulmonary dendritic cells to promote type $2 \mathrm{~T}$-cell responses by an indirect mechanism. American journal of physiology Lung cellular and molecular physiology. 2015;309(10):L1208-18.

53. Tjota MY, Hrusch CL, Blaine KM, Williams JW, Barrett NA, Sperling AI. Signaling through FcRgamma-associated receptors on dendritic cells drives IL-33-dependent TH2-type responses. The Journal of allergy and clinical immunology. 2014;134(3):706-13 e8.

54. Kim LK, Morita R, Kobayashi Y, Eisenbarth SC, Lee CG, Elias J, et al. AMCase is a crucial regulator of type 2 immune responses to inhaled house dust mites. Proceedings of the National Academy of Sciences of the United States of America. 2015;112(22):E2891-9.

55. Fan E, Needham DM, Stewart TE. Ventilatory management of acute lung injury and acute respiratory distress 
syndrome. Jama. 2005;294(22):2889-96.

56. Rubenfeld GD, Caldwell E, Peabody E, Weaver J, Martin DP, Neff M, et al. Incidence and outcomes of acute lung injury. The New England journal of medicine. 2005;353(16):1685-93.

57. Wheeler AP, Bernard GR. Acute lung injury and the acute respiratory distress syndrome: a clinical review. Lancet. 2007;369(9572):1553-64.

58. Murray CJ, Lopez AD. Evidence-based health policy--lessons from the Global Burden of Disease Study. Science. 1996;274(5288):740-3.

59. Kearley J, Silver JS, Sanden C, Liu Z, Berlin $\mathrm{AA}$, White $\mathrm{N}$, et al. Cigarette smoke silences innate lymphoid cell function and facilitates an exacerbated type I interleukin-33-dependent response to infection. Immunity. 2015;42(3):566-79.

60. Xia J, Zhao J, Shang J, Li M, Zeng Z, Zhao J, et al. Increased IL-33 expression in chronic obstructive pulmonary disease. American journal of physiology Lung cellular and molecular physiology. 2015;308(7):L619-27.

61. Pace E, Di Sano C, Sciarrino S, Scafidi V, Ferraro M, Chiappara G, et al. Cigarette smoke alters IL-33 expression and release in airway epithelial cells. Biochimica et biophysica acta. 2014;1842(9):1630-7.

62. Barrera L, Montes-Servin E, Barrera A, Ramirez-Tirado LA, Salinas-Parra F, Banales-Mendez JL, et al. Cytokine profile determined by data-mining analysis set into clusters of non-small-cell lung cancer patients according to prognosis. Annals of oncology : official journal of the European Society for Medical Oncology / ESMO. 2015;26(2):428-35.

63. Kempf W, Zollinger T, Sachs M, Ullmer E, Cathomas G, Dirnhofer S, et al. Granulomas are a source of interleukin-33 expression in pulmonary and extrapulmonary sarcoidosis. Human pathology. 2014;45(11):2202-10.

64. Naumnik W, Naumnik B, Niklinska W, Ossolinska M, Chyczewska E. Interleukin-33 as a New Marker of Pulmonary Sarcoidosis. Advances in experimental medicine and biology. 2015;866:1-6.

65. Luzina IG, Kopach P, Lockatell V, Kang PH, Nagarsekar A, Burke AP, et al. Interleukin-33 potentiates bleomycin-induced lung injury. American journal of respiratory cell and molecular biology. 2013;49(6):999-1008.

66. Li D, Guabiraba R, Besnard AG, Komai-Koma M, Jabir MS, Zhang L, et al. IL-33 promotes ST2-dependent lung fibrosis by the induction of alternatively activated mac- rophages and innate lymphoid cells in mice. The Journal of allergy and clinical immunology. 2014;134(6):1422-32 e11.

67. Ampawong S, Chaisri U, Viriyavejakul P, Prapansilp P, Grau GE, Turner GD, et al. A potential role for interleukin-33 and gamma-epithelium sodium channel in the pathogenesis of human malaria associated lung injury. Malaria journal. 2015;14(1):389.

68. Martinez-Gonzalez I, Roca O, Masclans JR, Moreno R, Salcedo MT, Baekelandt V, et al. Human mesenchymal stem cells overexpressing the IL-33 antagonist soluble IL-1 receptor-like-1 attenuate endotoxin-induced acute lung injury. American journal of respiratory cell and molecular biology. 2013;49(4):552-62.

69. Pfeffer PE, Chen YH, Woszczek G, Matthews NC, Chevretton E, Gupta A, et al. Vitamin D enhances production of soluble ST2, inhibiting the action of IL-33. The Journal of allergy and clinical immunology. 2015;135(3):824-7 e3.

70. Cohen ES, Scott IC, Majithiya JB, Rapley L, Kemp BP, England E, et al. Oxidation of the alarmin IL-33 regulates ST2-dependent inflammation. Nature communications. 2015;6:8327.

71. Taniguchi A, Miyahara N, Waseda K, Kurimoto E, Fujii U, Tanimoto Y, et al. Contrasting roles for the receptor for advanced glycation end-products on structural cells in allergic airway inflammation vs. airway hyperresponsiveness. American journal of physiology Lung cellular and molecular physiology. 2015;309(8):L789-800.

72. Long Q, Huang W, Yao Y, Yang X, Sun W, Jin X, et al. Virus-like particles presenting interleukin-33 molecules: immunization characteristics and potentials of blockingIL-33/ST2 pathway in allergic airway inflammation. Human vaccines $\&$ immunotherapeutics. 2014;10(8):2303-11.

73. Lei Y, Boinapally V, Zoltowska A, Adner M, Hellman L, Nilsson G. Vaccination against IL-33 Inhibits Airway Hyperresponsiveness and Inflammation in a House Dust Mite Model of Asthma. PloS one. 2015;10(7):e0133774.

74. Murakami I, Zhang R, Kubo M, Nagaoka K, Eguchi E, Ogino K. Rebamipide suppresses mite-induced asthmatic responses in NC/Nga mice. American journal of physiology Lung cellular and molecular physiology. 2015;309(8):L8728.

75. Verheijden KA, Akbari P, Willemsen LE, Kraneveld AD, Folkerts G, Garssen J, et al. Inflammation-induced expression of the alarmin interleukin 33 can be suppressed by galacto-oligosaccharides. International archives of allergy and immunology. 2015;167(2):127-36. 